\section{Treatment of Localized}

\section{Gingival Recessions}

\section{Part III. Comparison of Results Obtained With Lateral Sliding and Coronally Repositioned Flaps}

by

\author{
EMILIO A. GuINARD, D.D.S., M.S.* \\ RAUl G. CAFFESSE, D.D.S., M.S., DR. \\ ODONT. $\dagger$
}

LOCALIZED GINGIVAL recessions often require some form of mucogingival surgery. The recession also may be associated with some other periodontal problem such as frenum or muscle pull, minimal width or absence of attached gingiva, persistent inflammation, or root hypersensitivity, which might warrant treatment. In some cases, a localized gingival recession presents an esthetic problem, which may likewise be an indication for treatment. ${ }^{1}$

Clinical studies have shown that the lateral sliding flap operation, ${ }^{2,3}$ and the coronally repositioned flap with a free gingival graft ${ }^{4-6}$ are predictable surgical procedures in covering denuded root surfaces. Comparison of these two procedures in a controlled human clinical situation has not been reported.

The purpose of this study is to compare the biometric changes obtained on the recipient as well as on the donor or control tooth after performing a lateral sliding flap or a coronally repositioned flap with a free gingival graft in order to determine whether the expected results are similar after either procedure. Furthermore, a possible correlation between the amount of tissue coverage with these procedures on the width and depth of the recession will be tested.

\section{Materials ANd Methods}

A total of 23 persons with 28 teeth having localized gingival recessions were selected. There were 14 females and 9 males. Their age ranged from 19 to 68 years, with a mean age of 35 years. The treatment modality for each gingival recession was randomly selected. Fourteen recessions were treated with a lateral sliding flap and 14 were treated with a coronally repositioned flap. The

\footnotetext{
* Periodontics, The University of Michigan School of Dentistry, Ann Arbor, Mich 48109 U.S.A. Present Address: Apartado 6183, Panama 5 R.P. Panama.

† Professor, Department of Periodontics, The University of Michigan School of Dentistry, Ann Arbor, Mich 48109 U.S.A. For reprints, please write to Dr. R. G. Caffesse.
}

methodology used and the results obtained with the individual techniques have been reported separately., 6

All data obtained were analyzed statistically to determine the significance of the results after the use of the lateral sliding flap and the coronally repositioned flap. The results with both techniques were compared to test the following hypotheses:

First hypothesis: Mean change of one procedure equals mean change of the second procedure for a given time.

Second hypothesis: Mean change for a given time period is the same for all the beginning condition groups.

The statistical tests utilized to evaluate the above hypotheses were: (a) Two sample $t$ test (first hypothesis), and (b) Analysis of variance (second hypothesis). The hypothesis was rejected if the probability ratio ( $P$-value) was less than 0.05 .

\section{RESULTS}

Table 1 shows the changes that occurred on the recipient tooth at different time intervals when both surgical procedures were compared. Graphs, 1, 2 and 3 represent those changes occurring in the location of the free gingival margin, sulcus depth and width of attached gingiva, respectively.

A mean gain of soft tissue coverage averaging 2.71 $\mathrm{mm}$ resulted from both surgical procedures at 180 days. No significant differences occurred at any given time interval between the two surgical modalities $(P>0.05)$ (Graph 1).

No significant differences $(P>0.05)$ in sulcus depth occurred at any given time either (Graph 2).

The main gain in width of keratinized gingiva averaged $3.21 \mathrm{~mm}$. No significant differences $(P>0.05)$ occurred at any given time when both surgical procedures were compared (Graph 3).

Table 2 shows the changes occurring on the donor or control teeth (depending on the technique) at different time intervals when both surgical procedures were compared.

Significant differences $(P \leq 0.001)$ occurred in the location of the free gingival margin after surgical intervention, since gingival recession was a result after a lateral sliding flap, while no change in the location of the free gingival margin was evidenced by a coronally repositioned flap. No significant change $(P>0.05)$ occurred from 30 to 180 days.

Significant differences $(P \leq 0.001)$ occurred in sulcus depth at 30 days, with greater reduction where a lateral sliding flap was performed. A slight significant difference $(P \leq 0.01)$ in sulcus depth was present at 90 days, also. However, this difference was even less significant $(P \leq$ $0.02)$ at 180 days. No significant changes $(P>0.05)$ occurred from 30 to 180 days.

A significant change $(P \leq 0.001)$ in the width of keratinized gingiva occurred at 30 and 90 days, with greater loss when a lateral sliding flap was performed. Also, a less significant change $(P \leq 0.01)$ occurred at 180 
TABLE 1. Comparison of Mean Changes on Recipient Teeth After Lateral Sliding and Coronally Repositioned Flap Procedures

\begin{tabular}{|c|c|c|c|c|c|c|c|c|}
\hline & & Initial & 30 days & Change & 90 days & Change & 180 days & Change \\
\hline $\begin{array}{l}\text { Cemento-enamel junction } \\
\text { gingival margin }\end{array}$ & $\begin{array}{l}\text { LSF } \\
\text { CRF }\end{array}$ & $\begin{array}{l}3.89 \mathrm{~mm} \\
4.25 \mathrm{~mm}\end{array}$ & $\begin{array}{l}1.07 \mathrm{~mm} \\
1.60 \mathrm{~mm}\end{array}$ & $\begin{array}{l}2.82 \mathrm{~mm} \\
2.65 \mathrm{~mm}\end{array}$ & $\begin{array}{l}1.28 \mathrm{~mm} \\
1.75 \mathrm{~mm}\end{array}$ & $\begin{array}{l}2.61 \mathrm{~mm} \\
2.50 \mathrm{~mm}\end{array}$ & $\begin{array}{l}1.20 \mathrm{~mm} \\
1.52 \mathrm{~mm}\end{array}$ & $\begin{array}{l}2.69 \mathrm{~mm} \\
2.73 \mathrm{~mm}\end{array}$ \\
\hline Sulcus depth & $\begin{array}{l}\text { LSF } \\
\text { CRF }\end{array}$ & $\begin{array}{l}2.00 \mathrm{~mm} \\
1.64 \mathrm{~mm}\end{array}$ & $\begin{array}{l}1.64 \mathrm{~mm} \\
1.42 \mathrm{~mm}\end{array}$ & $\begin{array}{l}0.36 \mathrm{~mm} \\
0.22 \mathrm{~m}\end{array}$ & $\begin{array}{l}1.89 \mathrm{~mm} \\
1.21 \mathrm{~mm}\end{array}$ & $\begin{array}{l}0.11 \mathrm{~mm} \\
0.43 \mathrm{~mm}\end{array}$ & $\begin{array}{l}1.57 \mathrm{~mm} \\
1.14 \mathrm{~mm}\end{array}$ & $\begin{array}{l}0.43 \mathrm{~mm} \\
0.50 \mathrm{~mm}\end{array}$ \\
\hline $\begin{array}{l}\text { Gingival margin- } \\
\text { mucogingival line }\end{array}$ & $\begin{array}{l}\text { LSF } \\
\text { CRF }\end{array}$ & $\begin{array}{l}1.35 \mathrm{~mm} \\
0.87 \mathrm{~mm}\end{array}$ & $\begin{array}{l}4.42 \mathrm{~mm} \\
4.10 \mathrm{~mm}\end{array}$ & $\begin{array}{l}3.07 \mathrm{~mm} \\
3.23 \mathrm{~mm}\end{array}$ & $\begin{array}{l}4.46 \mathrm{~mm} \\
4.07 \mathrm{~mm}\end{array}$ & $\begin{array}{l}3.11 \mathrm{~mm} \\
3.20 \mathrm{~mm}\end{array}$ & $\begin{array}{l}4.50 \mathrm{~mm} \\
4.14 \mathrm{~mm}\end{array}$ & $\begin{array}{l}3.15 \mathrm{~mm} \\
3.27 \mathrm{~mm}\end{array}$ \\
\hline
\end{tabular}

Statistically not significant, $P>0.05$.

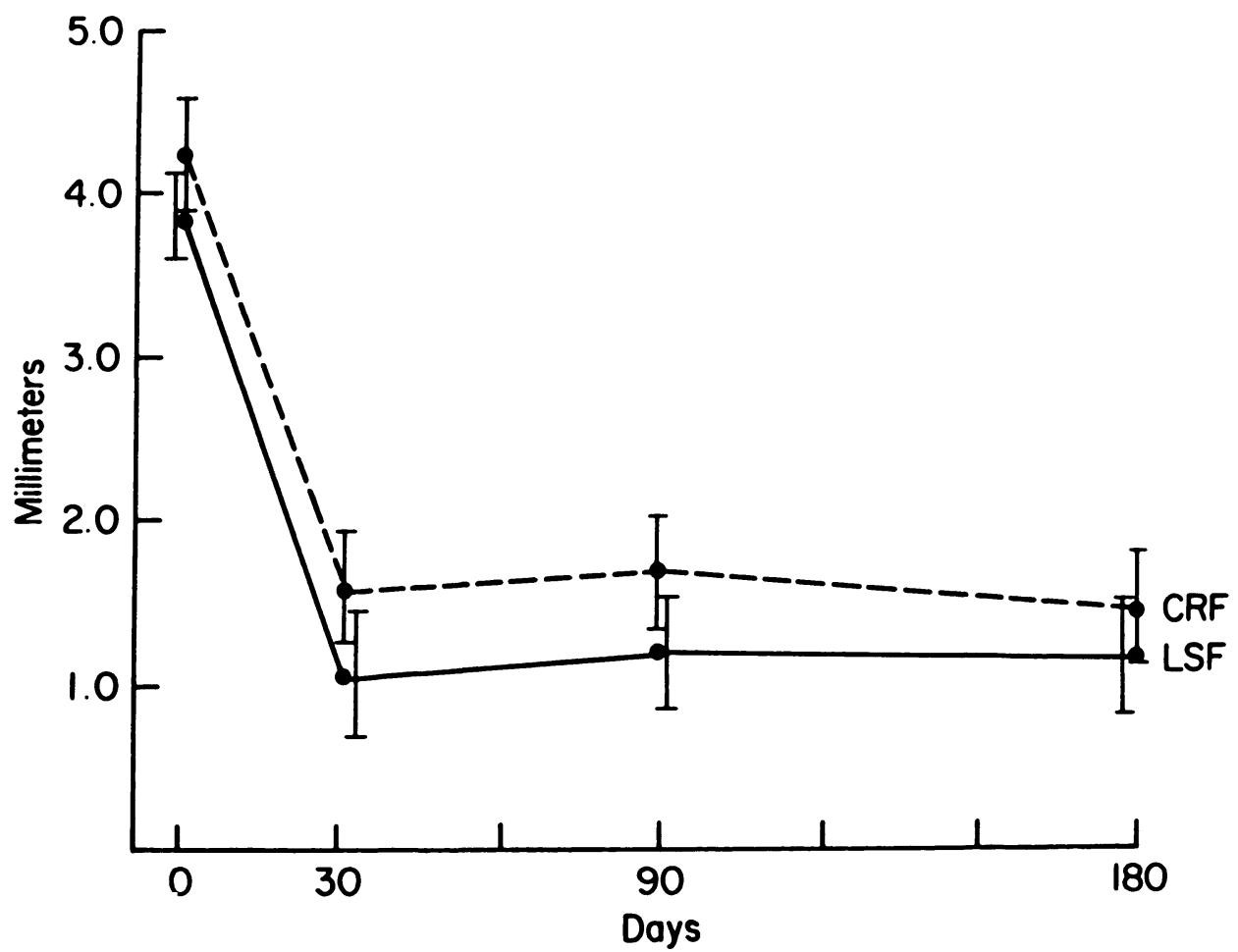

GRAPH 1. Mean changes from CEJ to gingival.margin of recipient tooth.

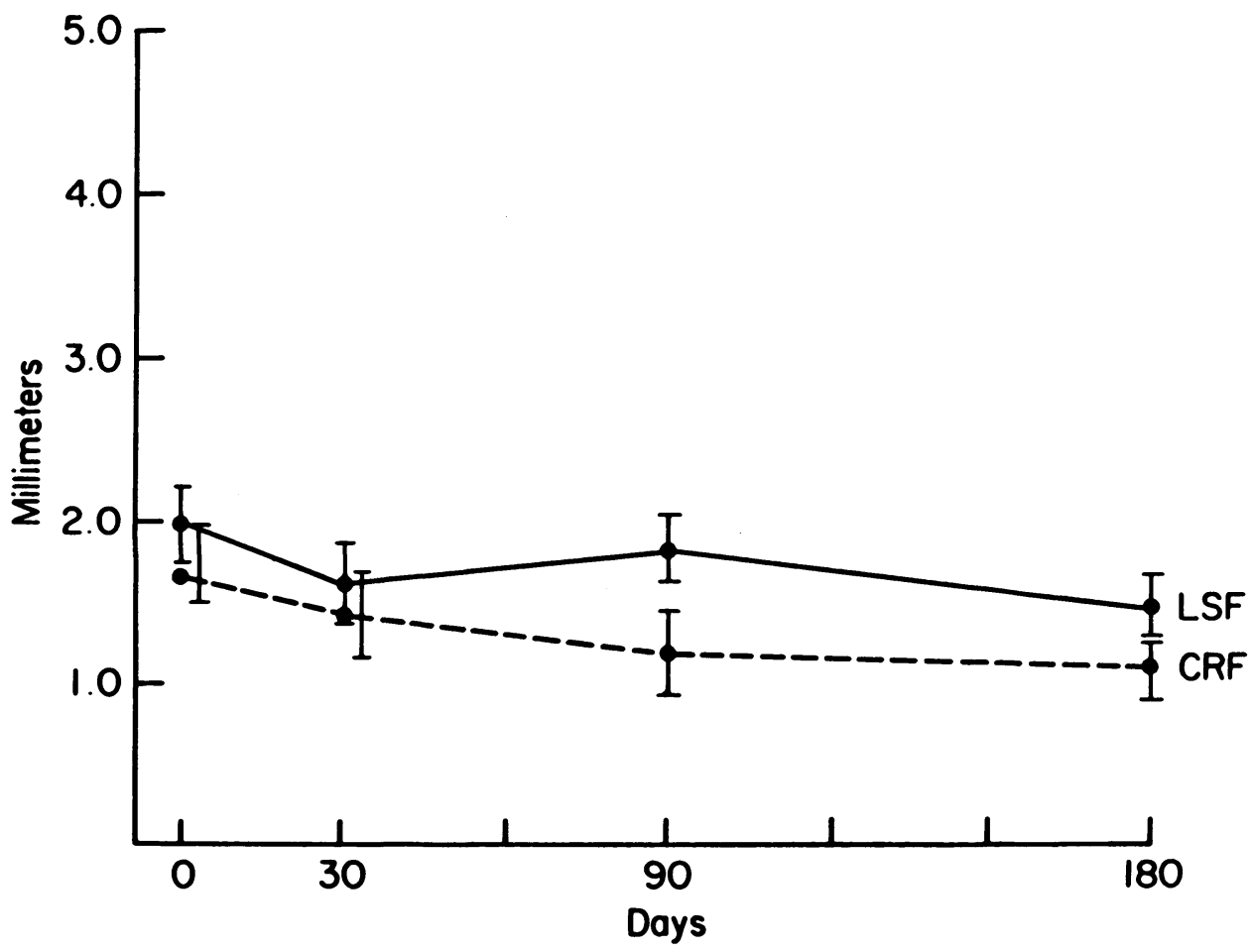

GRAPH 2. Mean sulcus depth changes of recipient tooth. 


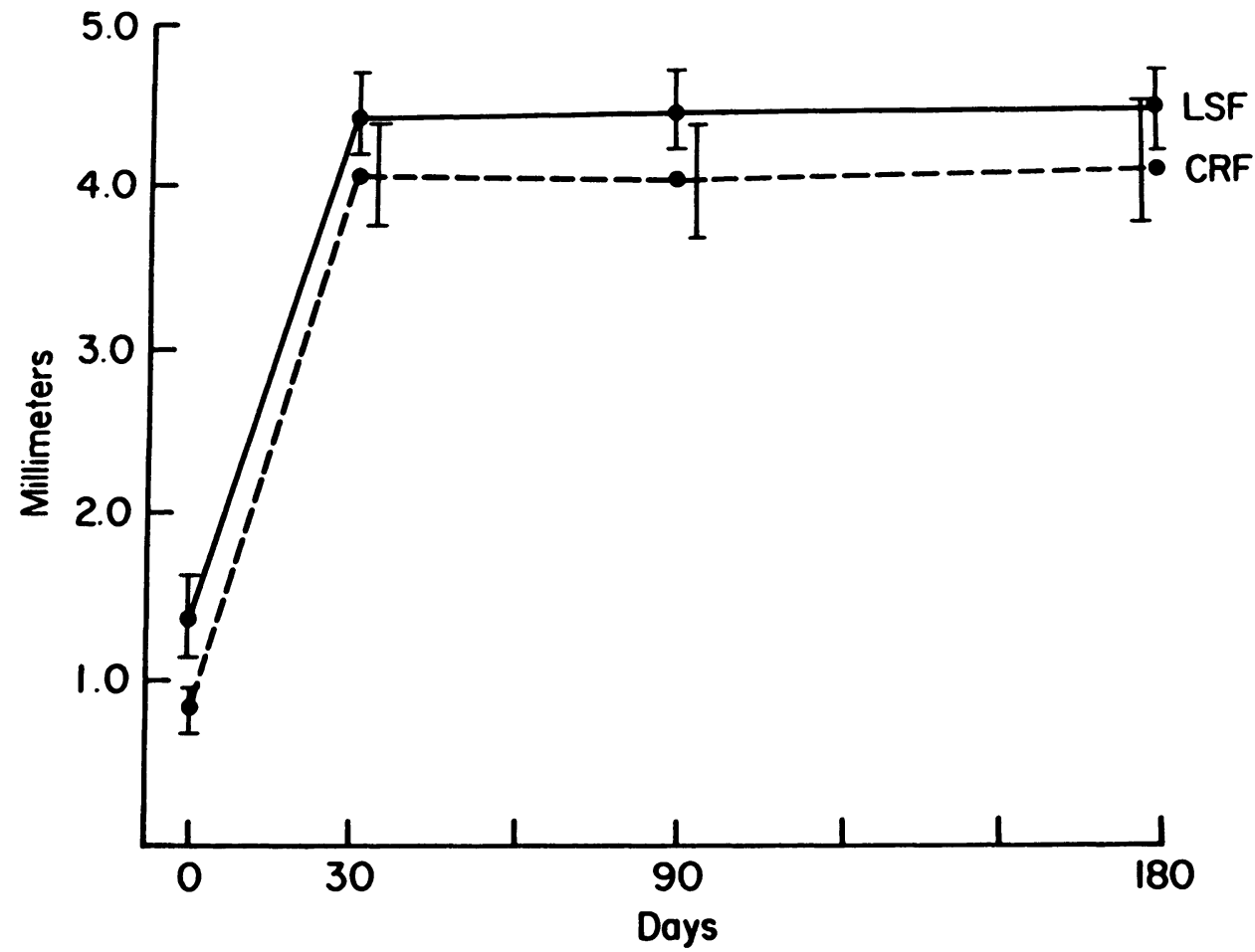

GRAPH 3. Mean changes from gingival margin to MGL of recipient tooth.

TABLE 2. Comparison of Mean Changes on Donor or Control Teeth After Lateral Sliding and Coronally Repositioned Flap Procedures

\begin{tabular}{|c|c|c|c|c|c|c|c|c|}
\hline & & Initial & 30 days & Change & 90 days & Change & 180 days & Change \\
\hline $\begin{array}{l}\text { Cemento-enamel junction } \\
\text { gingival margin }\end{array}$ & $\begin{array}{l}\text { LSF } \\
\text { CRF }\end{array}$ & $\begin{array}{l}0.32 \mathrm{~mm} \\
0.96 \mathrm{~mm}\end{array}$ & $\begin{array}{l}1.62 \mathrm{~mm} \\
0.96 \mathrm{~mm}\end{array}$ & $\begin{array}{l}1.30 \mathrm{~mm}^{\star} \\
0.00 \mathrm{~mm}\end{array}$ & $\begin{array}{l}1.42 \mathrm{~mm} \\
0.89 \mathrm{~mm}\end{array}$ & $\begin{array}{l}1.10 \mathrm{~mm}^{*} \\
0.05 \mathrm{~mm}^{2}\end{array}$ & $\begin{array}{l}1.42 \mathrm{~mm} \\
0.89 \mathrm{~mm}\end{array}$ & $\begin{array}{l}1.10 \mathrm{~mm} \\
0.05 \mathrm{~mm}^{2}\end{array}$ \\
\hline Sulcus depth & $\begin{array}{l}\text { LSF } \\
\text { CRF }\end{array}$ & $\begin{array}{l}1.53 \mathrm{~mm} \\
1.28 \mathrm{~mm}\end{array}$ & $\begin{array}{l}0.63 \mathrm{~mm} \\
1.53 \mathrm{~mm}\end{array}$ & $\begin{array}{l}0.90 \mathrm{~mm}^{*} \\
0.25 \mathrm{~mm}^{2}\end{array}$ & $\begin{array}{l}0.96 \mathrm{~mm} \\
1.53 \mathrm{~mm}\end{array}$ & $\begin{array}{l}0.57 \mathrm{~mm}_{\star \star} \\
0.25 \mathrm{~mm}^{2}\end{array}$ & $\begin{array}{l}0.96 \mathrm{~mm} \\
1.50 \mathrm{~mm}\end{array}$ & $\begin{array}{l}0.57 \mathrm{~mm}_{\star \star \star} \\
0.22 \mathrm{~mm}\end{array}$ \\
\hline $\begin{array}{l}\text { Gingival margin- } \\
\text { mucogingival line }\end{array}$ & $\begin{array}{l}\text { LSF } \\
\text { CRF }\end{array}$ & $\begin{array}{l}4.71 \mathrm{~mm} \\
3.96 \mathrm{~mm}\end{array}$ & $\begin{array}{l}3.39 \mathrm{~mm} \\
4.17 \mathrm{~mm}\end{array}$ & $\begin{array}{l}1.32 \mathrm{~mm}_{\star} \\
0.21 \mathrm{~mm}\end{array}$ & $\begin{array}{l}3.28 \mathrm{~mm} \\
4.17 \mathrm{~mm}\end{array}$ & $\begin{array}{l}1.43 \mathrm{~mm}_{\star} \\
0.21 \mathrm{~mm}^{2}\end{array}$ & $\begin{array}{l}3.46 \mathrm{~mm} \\
4.07 \mathrm{~mm}\end{array}$ & $\begin{array}{l}1.25 \mathrm{~mm}_{\star \star} \\
0.11 \mathrm{~mm}\end{array}$ \\
\hline
\end{tabular}

* Statistically significant, $P \leq 0.001$.

** Statistically significant, $P \leq 0.01$.

*** Statistically significant, $P \leq 0.02$.

TABLE 3. Mean Change on the Amount of Coverage According to the Width and Depth of the Recession

\begin{tabular}{|c|c|c|c|c|c|c|c|}
\hline \multicolumn{8}{|c|}{ Analysis of Variance } \\
\hline & $\underline{N-S}$ & $\underline{N-D}$ & $\underline{W-S}$ & $\underline{W-D}$ & $\underline{\mathbf{f}}$ & $\underline{\text { df }}$ & sig. \\
\hline $0-30$ days & -2.00 & -2.56 & -3.00 & -3.10 & 2.71 & 3,24 & 0.06 \\
\hline 0-90 days & -1.90 & -2.50 & -2.74 & -2.83 & 1.64 & 3,24 & 0.20 \\
\hline $0-180$ days & -2.20 & -2.71 & -2.84 & -2.90 & 0.81 & 3,24 & 0.49 \\
\hline $30-90$ days & 0.10 & 0.62 & 0.26 & 0.27 & 0.74 & 3,24 & 0.53 \\
\hline $30-180$ days & -0.20 & -0.15 & 0.16 & 0.20 & 1.26 & 3,24 & 0.30 \\
\hline \multirow[t]{2}{*}{$90-180$ days } & -0.30 & -0.21 & -0.10 & -0.70 & 0.32 & 3,24 & 0.81 \\
\hline & $N=5$ & $N=8$ & $N=5$ & $N-10$ & & & \\
\hline
\end{tabular}

days. No significant changes $(P>0.05)$ occurred from 30 to 180 days.

Table 3 shows the mean change that occurred on the amount of coverage according to the width and the depth of the treated recession, irrespective of the surgical technique used. Recessions were classified as: (a) narrow- shallow (width $\leq 3.5 \mathrm{~mm}$, depth $<4.0 \mathrm{~mm}$ ); (b) narrowdeep (width $\leq 3.5 \mathrm{~mm}$, depth $\geq 4.0 \mathrm{~mm}$ ); (c) wideshallow (width $>3.5 \mathrm{~mm}$, depth $<4.0 \mathrm{~mm}$ ); and (d) wide-deep (width $>3.5 \mathrm{~mm}$, depth $\geq 4.0 \mathrm{~mm}$ ). No significant differences $(P>0.05)$ occurred during the testing period in any of the four groups considered. 


\section{Discussion}

The results obtained in the present study show that areas of gingival recession are reduced dramatically both by lateral sliding and coronally repositioned flaps. A mean gain of $2.71 \mathrm{~mm}$ of soft tissue coverage resulted after both procedures at 6 months postoperatively. The values of soft tissue coverage remained stable after 30 days. This stability of results after 30 days was observed both on the recipient as well as on the donor tooth for all variables tested, including sulcus depth and width of keratinized gingiva.

A significant increase in the width of keratinized gingiva occurred on the recipient tooth with both surgical procedures, averaging $3.21 \mathrm{~mm}$ at 6 months.

Comparison of the results of both surgical procedures on the recipient tooth demonstrated that differences of gingival recession, sulcus depth and width of keratinized gingiva were not statistically significant $(P>0.05)$. Thus, both surgical procedures provide a satisfactory solution in the treatment of gingival recessions.

When changes on the neighboring tooth (either donor or control) are compared, it is obvious that significant negative changes occurred after performing a lateral sliding flap. Significant increase in the amount of gingival recession $(1.10 \mathrm{~mm})$ and a significant reduction in the width of keratinized gingiva $(1.25 \mathrm{~mm})$ were found 6 months after surgery.

No changes occurred in any of the variables evaluated on the teeth adjacent to the recession when a coronally repositioned flap was performed, since they remained undisturbed by this procedure.

\section{Deep-Wide vs Deep-Narrow Recessions}

Clinically speaking, it is assumed that the most difficult type of gingival cleft to be covered by means of any pedicle periodontal flap is the deep-wide recession and the easiest one is the deep-narrow.

An attempt was made to determine if there was any difference in covering localized gingival recessions according to their width and depth. They were grouped as follows: (a) narrow-shallow, (b) narrow-deep, (c) wideshallow, and (d) wide-deep. Due to the fact that the results obtained in this study showed no significant variations on the recipient tooth when the lateral sliding flap and the coronally repositioned flap were performed, both procedures were pooled together and an analysis of variance was performed. It was interesting to observe that no significant variations were found in any of the four groups tested throughout the experiment.

The "take" of the lateral sliding and the coronally repositioned flaps over a denuded root surface depends more on the height of the papillae present preoperatively on each side of the defect, and thus, on the size of the bed that can be prepared there, than on the width and depth of the recession. The height of the papillae adjacent to the defect prior to surgery also determines to some extent the amount of soft tissue coverage on the recipient tooth. In this study a complete soft tissue coverage (100\%) was not obtained in any case when one of the papillae adjacent to the recession was about $2.0 \mathrm{~mm}$ apical to the cementoenamel junction. In such cases, the amount of "papillary bed" was also reduced.

\section{Possible Clinical Indications}

According to the results obtained in the present biometric study, the lateral sliding and the coronally repositioned flaps can provide a satisfactory solution to the problem of localized gingival recessions.

However, in some instances a localized gingival recession might be much better treated by one of these two surgical procedures.

The main risk in performing a lateral sliding flap is the raising of a flap which comprises the entire marginal gingiva. Consequently denudation of the bone on the donor tooth is part of the operation. This may create permanent bone loss ${ }^{7,8}$ and gingival recession. In some cases, this situation may be aggravated if an existing recession is accompanied by a very thin bone at the donor tooth prior to surgery. In this case, if a lateral sliding flap is performed, the final clinical result could be the displacement of the recession from one tooth to another, with the possible consequence of a deeper recession at the donor tooth. A coronally repositioned flap is strongly indicated in such an instance, since the teeth adjacent to the defect remain undisturbed by this surgical procedure.

Prior to the introduction of the coronally repositioned flap, Knowles and Ramfjord ${ }^{9}$ performed a lateral sliding flap and placed a free palatal mucosa graft on the donor tooth to avoid denudation of the bone, especially when it was very thin. Recently, Irwin ${ }^{10}$ reported a procedure similar to that described by Knowles and Ramfjord.

In cases, where on the donor tooth the bone is very thick and the gingival margin is located at the cementoenamel junction, the lateral sliding flap and the coronally repositioned flap are both indicated. In this specific situation the lateral sliding flap offers the advantage that it can be done in only one surgical appointment.

Difficulties can arise also when there is only a narrow zone of attached gingiva on the possible donor tooth. In such cases, Bjorn ${ }^{11}$ increased the gingival width by using a free gingival graft laterally to the recession and performed a lateral sliding flap 1 month later, leaving the marginal gingiva on the donor tooth undisturbed. However, the bone was left completely exposed on the donor tooth with the possibilities of permanent bone loss, which could be converted to a small fenestration in the future.

Cohen and Ross ${ }^{12}$ performed the double papillae flap to cover denuded root surfaces when a sufficient amount of attached gingiva was not present on the possible donor teeth. Although the results of this technique have not been tested experimentally, its predictability does not seem to be high; its most common failure being the appearance of a deep and narrow cleft at the middle surface of the root. 
Therefore, in the frequent situations when there is lack of attached gingiva adjacent to a gingival recession, the coronally repositioned flap is highly indicated. The teeth adjacent to the gingival recession remain undisturbed and the results obtained in covering the denuded root surfaces have been very satisfactory, since the attached gingiva needed is previously created by placing a free gingival graft apically to the recession.

In some cases localized gingival recessions present an esthetic problem, which likewise may be an indication for treatment. In such an instance, the lateral sliding flap is the treatment of choice due to the whitish appearance that the coronally repositioned flap usually presents. This whitish appearance is due to the fact that the free gingival graft placed apically to the recession maintains its original tissue characteristics after it has been grafted.

Multiple recessions without pocketing but lacking sufficient attached gingiva may present a problem due to the frequent gingival inflammation present in those areas, in spite of good oral hygiene. ${ }^{13}$ Presently these special situations are treated with a free gingival graft. Bernimoulin ${ }^{4,5}$ has obtained successful results with the coronally repositioned flap in these cases by creating a new band of attached gingiva and covering the recession at the same time. Gingival inflammation and root hypersensitivity are reduced, thus facilitating better oral hygiene performance by the patients.

\section{SUMmary}

This study was undertaken to evaluate biometrically changes relative to the recipient as well as the donor tooth with regard to gingival recession, sulcus depth and width of keratinized gingiva following a coronally repositioned flap with a free gingival graft (Bernimoulin, 1973) and a lateral sliding flap, (Grupe and Warren, 1956), and to compare the results obtained with both techniques.

A total of 23 persons with 28 teeth having localized gingival recessions were selected. The treatment modality for each gingival recession was randomly selected. Clinical measurements were taken at the following times: prior to surgery, 1,3, and 6 months after surgery.

A mean gain of $2.71 \mathrm{~mm}$ of soft tissue coverage over the denuded root was recorded 6 months postoperatively following both procedures. The mean gain in width of keratinized gingiva averaged $3.21 \mathrm{~mm}$ and was similar following both procedures.

There was no significant difference between the two methods in effectiveness of covering denuded root surfaces. However, significantly more recession occurred postsurgically on the donor tooth after the lateral sliding flap compared with the teeth adjacent to the coronally repositioned flap.

The values for gingival recession, sulcus depth and width of keratinized gingiva on the recipient tooth as well as on the donor tooth remained stable after both procedures from 30 days postoperatively.

No significant variations were found in the amount of soft tissue coverage relative to the width and depth of the recession.

\section{ConClusions}

1. The lateral sliding flap and the coronally repositioned flap provide a satisfactory solution in the treatment of localized gingival recessions.

2. A similar amount of root coverage is expected from both procedures.

3. No significant correlation was found between the amount of soft tissue coverage and the depth and width of the treated gingival recessions.

\section{REFERENCES}

1. Guinard, E., and Caffesse, R.: Localized gingival recession. II. Treatment. Periodontal Abstracts, 25: 10, 1977.

2. Albano, E., Caffesse, R. G., and Carranza, F.: Estudio biometrico de colgajos desplazados lateralmente. Rev Asoc Odontol Argentina 61: 12, 1973.

3. Guinard, E., and Caffesse, R. G.: Treatment of localized gingival recessions. Part I. Lateral sliding flap. J Periodontol 49: $351,1978$.

4. Bernimoulin, J.: Deckung gingivaler rezessionen mit koronaler verschiebungsplastik. Deut. Zahnaertl. Zeitschr. 28: 1222, 1973.

5. Bernimoulin, J.: Coronally repositioned periodontal flap. Clinical evaluation after one year. J Clin Periodont 2: 1, 1975.

6. Caffesse, R. G., and Guinard, E.: Treatment of localized gingival recessions. Part II. Coronally repositioned flap with a free gingival graft. $J$ Periodontol 49: 357, 1978.

7. Costich, E., and Ramfjord, S.: Healing after exposure of periosteum and labial bone in periodontal surgery. I.A.D.R. Abstr. No. 12, 1964.

8. Wilderman, M., Wentz, F., and Orban, B.: Histogenesis of repair after mucogingival surgery. J Periodontol 31: 283, 1960.

9. Knowles, J., and Ramfjord, S.: The lateral sliding flap with a free gingival graft. University of Michigan Dental School, Video Cassette, 1971.

10. Irwin, R.: Combined use of the gingival graft and rotated pedicle procedures: Case reports. J Periodontol 48: 38, 1977.

11. Björn, H.: Coverage of denuded root surfaces with a lateral sliding flap. Use of free gingival grafts. Odontol Revy 22: 37, 1971.

12. Cohen, D., and Ross, S.: The double papillae flap in periodontal therapy. J Periodontol 39: 65, 1968.

13. Lang, N., and Löe, H.: The relationship between the width of keratinized gingiva and gingival health. $J$ Periodontol 43: 623, 1972. 